\title{
Development of agribusiness industry in India: opportunities, challenges and solutions
}

\begin{abstract}
Agribusiness industry deals with the production, processing, marketing and shipments of agricultural produce. It covers a variety of industrial, manufacturing and processing activities based on agricultural raw materials as also activities and services that go as inputs to agriculture. The development of the agribusiness industry can help stabilize and make agriculture more lucrative and create employment opportunities both at the production and marketing stages. This paper tries to explore the opportunities and challenges of agribusiness sector in the country. There is no doubt that agribusiness industry has a lot of potential to improve rural incomes and can play a very significant role in creation of employment for rural youths. The present study focused on the need to critically look at how can people get the opportunities and how can alleviate the constraints faced by the agribusiness sector in the country. There is also need to review the technological supply chain and storage facilities for a wide range of commodities produced in the country. A well-developed agribusiness system in country can make enables millions of farmers and agripreneurs to capitalize the emerging opportunities of the agriculture and allied sector. The development of agribusiness sector is the need of future to strengthening rural employment, food security and living standard of peoples in the country.
\end{abstract}

KEY WORDS : Agribusiness, Food security, Food processing, Contract farming and Agri retailing

How to cite this paper : Bairwa, Shoji Lal and Singh, Udhav Prasad (2015). Development of agribusiness industry in India: opportunities, challenges and solutions. Internat. J. Com. \& Bus. Manage, 8(1) : 88-93.

\section{MEMBERS OF THE RESEARCH FORUM}

Correspondence to:

SHOJI LAL BAIRWA, Department of Agricultural Economics, Bihar Agricultural University, Sabour, BHAGALPUR (BIHAR) INDIA

Email: smabm.bhu@ gmail.com

Authors' affiliations:

UDHAV PRASAD SINGH, Department of Agricultural Economics, Trihut College of Agriculture (R.A.U.), Dholi, (BIHAR) INDIA 